\title{
In vitro antibacterial potentials of the sensitive plant (Mimosa pudica) and bitter melon (Momordica charantia) leaf extracts and synthetic antibiotics against some bacteria isolates of Clarias gariepinus
}

\author{
Adekunle Adedoyin Idowu ${ }^{1}$, Azeez Ayodele Alimi ${ }^{1 *}$ (D), Adeleke Taofik Towolawi ${ }^{2}$, Abiodun Oluwole Akinde ${ }^{1}$, \\ Kolapo Fasina ${ }^{3}$ and Joy Aigbemekhe ${ }^{1}$
}

\author{
Address: \\ ${ }^{2}$ Department of Environmental Management and Toxicology, FUNAAB, Nigeria. \\ ${ }^{3}$ Department of Microbiology, FUNAAB, Nigeria. \\ *Corresponding author: Alimi Azeez Ayodele, alimiazees911@gmail.com \\ Received: 25-4-2020; Accepted: 6-12-2020; Published: 2-1-2021
}

${ }^{1}$ Department of Aquaculture and Fisheries Management, Federal University of Agriculture, Abeokuta (FUNAAB), Nigeria.

$\underline{10.21608 / \text { ejar.2020.28620.1007 }}$

\section{ABSTRACT}

This study investigated the antibacterial potentials of a sensitive plant (Mimosa pudica) and bitter melon (Momordica charantia) leaf extracts against bacterial isolates of Clarias gariepinus. Samples of infected $C$. gariepinus were collected and analysed microbiologically using standard methods. Isolated bacteria were subjected to sensitivity test with the leaves extracts from tested plants and ten synthetic antibiotics (Ciprofloxacine, chloramphenicol, Sparfloxacin, Augmentin, Centamycin, Perfloxacin, Ofloxacin, Streptomycin, Amoxacillin, and Septrin). Eight tested bacteria namely: Bacillus megaterium, B. subtilis, Klebsiella oxytoca, Aeromonas hydrophila, Citrobacter spp, Escherichia coli, Enterobacter spp. and Staphyllococcus aureus were identified. The results showed that the ethanolic extract of $M$. charantia possessed the highest effect against B. megaterium (Inhibition diameter, ID=20 mm), Enterobacter spp. (ID=25 mm), B. subtilis, A. hydrophilia (ID=23 mm) and Citrobacter spp. (ID=19 mm). However, ciprofloxacine showed antibacterial effect against Enterobacter spp. (ID=13.35 mm), S. aureus (ID=14.5 mm) and Klebsiella spp. (ID=15.1 mm). Phytochemical screening of tested plants revealed a higher quantity of some compounds of antimicrobial potentials in $M$. charantia than M. pudica such as alkaloids, phenols, flavonoids, saponin and terpenoids. Conclusively, this study confirmed that antibacterial potential of bitter melon ethanolic leaves extract and that it can be used as a control of some bacterial pathogens of $C$. gariepinus.

Keywords: Medicinal Plants, Leaves Extracts, Antimicrobials, Bacterial isolates

\section{INTRODUCTION}

Fisheries products are one of the cheapest source of animal protein for human, as well as their importance as a source of ingredients for livestock feed. Over $30 \%$ of fish consumed by a human is a product of aquaculture (Hastein et al., 2006). Infectious diseases can be transferred to human due to fish consumption and fish products. Fish pathogens are usually found on the body parts including sticky slime, skin and internal, gills and the gut. To control or prevent some devastating outbreaks of diseases, the use of chemotherapeutic and other conventional antimicrobials have been employed with limited results (Jadhav et al., 2006). While synthetic antibiotics undoubtedly have recorded significant successes in the management of diseases and infections through their -static and -cidal effects, it is not without limitations like side effects and microbial resistance. For thousands of years, the source of most medicinal agents has been from natural sources. In various part of the world, numerous medicinal plants are used on daily bases to cure or treat diseases (Nair et. al., 2005).

Laboratory studies on extracts from medicinal plants, especially higher plants, have been reported to contain substances that act as antifungal, antibacterial, and insecticidal (Satish et al., 2007; Okigbo and Ogbonnaya, 2006). About 25\% of prescribed drugs in the world are from plants origin (Rates, 2001) while in developing countries particularly in Nigeria, large populations have confidence in the utilization of natural phytomedicines. Medicinal plants are used to promote health and alleviate illness. This is because these contain biochemical substances which are antibacterial (Balakumar et al., 2011). The important biochemicals or active constituents of plants include flavonoids, tannins, alkaloids, and phenols (Kiruba et al., 2011; Rajan et al., 2011). The diverse range of bioactive molecules which are produced by plants made them an important source of different types of medicines.

However, screening of traditional herbal products by drug agency for standardization before use or sold in the market is crucial. In recent times, newly developed antibiotics are obtained from natural or semi-synthetic sources, however, approximately $20 \%$ of the world plants are being submitted for a pharmaceutical test (Sukanya et al., 2009). World Health Organization reported that medicinal plants would be the best source to derive a wide range of drugs (Santos et al., 1995). Thus, the systematic screening extracts of medicinal plants represent a continuous effort to find new potential compounds as antibacterial agents against multi-resistant bacteria (Sukanya et al., 2009). The advantage of antimicrobial substances of plant origin over synthetic drugs is that medicinal plants have fewer side effects and have a massive therapeutic potential to heal many infectious diseases. Antimicrobial properties of certain tropical medicinal plants were reported based on folklore information and only a few reports are available on their potential activities against certain fungi and pathogenic bacteria. Diverse chemical compounds with different biological activities could be produced from higher plants in large quantities (Harborne and Willans, 2000).

Mimosa pudica L. is a member of the family Mimosaceae. It is a perennial plant often planted for its curiosity value when the leaves are touched it folds inward and after some minute it reopens back. M. pudica is native to Brazil, but is now a pantropical weed (Doss et. al., 2011). With its pharmacological activities, $M$. pudica has been reported to contain alkaloid, glycoside, flavonoid and tannins. However, its aromatic properties have not been studied. Mormodica charantia L. belong to the family Cucarbitaceae, it is commonly called bitter melon/gourd, is a slender, tendril climbing, annual vine. This plant is a common food item of the tropics and it is utilized as anticancer, antidiabetic, and used for many ailments (Cefalu et al., 2008). Mormodica charantia is a potent hypoglycemic agent (Singh et al., 2011) against diabetes mellitus owing to the presence of alkaloids, insulin and charantin which is a component of steroidal sapogenins. 
Despite the many new types of research on the use of medicinal plants as therapeutic and prophylactic agents for the control of fish pathogens, there is a dearth of information on the utilization of Mimosa pudica and Mormodica charantia leave extract in the treatment of bacterial pathogen of Clarias gariepinus. Thus, the present study aimed at investigating the in vitro antibacterial potentials of $M$. pudica and $M$. charantia leave extracts and the commercially available synthetic antibiotics against some bacterial isolates of African mudcatfish, $C$. gariepinus.

\section{MATERIAL AND METHODS}

Plants sources and synthetic antibiotics:

Fresh leaves of Mimosa pudica and Mormodica charantia were collected from Fadama Farm at Federal University of Agriculture Abeokuta (FUNAAB) Southwest of Nigeria. Taxonomic identification and authentication of the plants were done at the Department of Forestry and Wildlife Management Herbarium, FUNAAB, Nigeria. The fresh leaves were washed under tap water, rinsed in sterile water, and thereafter shade-dried. The leaves were crushed into powder and used for extraction according to the modified method of Alimi (2015). The synthetic antibiotics were purchased from a registered and licensed pharmaceutical store - Idera Pharmacy, very close to FUNAAB, Abeokuta, Ogun State.

Phytochemical analysis of extract's samples:

One $\mathrm{ml}$ extract of each plant was diluted with $9 \mathrm{ml}$ of sterile water to make $10 \%$ dilution and the following phytochemical metabolites were estimated according to standard methods in duplicates. Different constituents such as steroids, tannins, alkaloids, phenol, saponin, flavonoids were determined according to the method of Edeoga et al. (2005).

\section{Fish samples:}

A number of 6 moribund and infected fish (C. gariepinus) were sourced from FUNAAB hatchery where students from Aquaculture and Fisheries Management regularly obtain fish seeds and adult fishes for experiments. Fish samples were obtained aseptically and transported in a sterile polythene bag to the laboratory immediately. Gills, livers, skins and intestines of fish samples were obtained between 2 and 3 hrs of collection and were stored in the refrigerator at a temperature not more than $6^{\circ} \mathrm{C}$.

\section{Preparation of samples:}

Ten grammes of the fish organs were cut out from the fish samples with a sterile knife. A sterile mortar was used to crush each organ into small pieces with $10 \mathrm{ml}$ of sterile water. One $\mathrm{ml}$ aliquot volume from the crushed organ was homogenized in a clear dried beaker contained $9 \mathrm{ml}$ of distilled water which gave a 1:10 dilution. This was repeated for all samples (Obi and Krakowiaka, 1983).

\section{Bacterial isolation and identification from C. gariepinus samples:}

Sample obtained were analysed in the microbiology laboratory, using standard microbiological methods under the complete aseptic condition at Aquaculture and Fisheries Management Department, FUNAAB. The swabs were inoculated on Nutrient agar manufactured from Oxoid (England). Mannitol salt agar (Oxoid, England) was used to inoculate swaps under the aerobic condition at $37^{\circ} \mathrm{C}$. Identification of isolated bacterial colonies was based on physiological, morphological and biochemical characters. The isolates were subjected to the following biochemical analysis, i.e. spore staining, indole, Gram reaction, methyl red motility, citrate, voges proskauer, carbohydrate fermentation, oxidase, Triple sugar ion and hydrogen sulfide production tests for identification of phosphate. Identification of bacteria carried out using Bergey's manual of systematic bacteriology (Holt et al., 1994). A host of many bacterial species such as Bacillus spp., Aeromonas spp., Escherichia coli, Klebsiella spp., Staphylococcus spp., Enterobacter spp. and Citrobacter spp. were isolated from the fish samples.

\section{Antibiotic sensitivity of the isolates:}

Diffusion methods using disc technique was used for the antibacterial sensitivity testing (Rahman and Hossain, 2010). The desired bacterial isolates were cultured in nutrient broth in a shaking incubator at $37^{\circ} \mathrm{C}$ for $24-48$ hours, until a turbid growth was observed, after which $50 \mu \mathrm{l}$ drops of broth cultures were added into a nutrient agar plate. A sterile glass rod ( $L$ shaped) was used to spread the culture on the plate before the antibiotics disc were dispensed onto the agar surface with sterile forceps. Five synthetic antibiotics discs were prepared; ciprofloxacin $(20 \mu \mathrm{g} / \mathrm{disc})$, gentamicin $(10 \mu \mathrm{g} / \mathrm{disc})$, erythromycin $(15 \mu \mathrm{g} / \mathrm{disc})$, chloramphenicol $(30 \mu \mathrm{g} / \mathrm{disc})$, and cephradine $(30 \mu \mathrm{g} / \mathrm{disc})$. Plates were inverted immediately after the discs have been inserted. The plates were later incubated for $16-18$ hours and were examined for inhibition zone (IZ). The IZ showed the antibacterial activities of discs and is measured in millimetre.

\section{Antibacterial assay of $M$. pudica and $M$. charantia extract to the isolated bacteria:}

Leaf extracts which are prepared from M. pudica and $M$. charantia were used as antibacterial to screen isolated bacteria from C. gariepinus. The fresh leaves from the plants were plucked and thoroughly washed in distilled water. The leaves were pounded in mortal-pestle to form a paste. Bacterial isolates were spread on the plates, inoculated with $10 \mu \mathrm{l}$ of the leaves extract and incubated at $37^{\circ} \mathrm{C}$ for about $12-24$ hours. The plant extracts were observed for $\mathrm{ZI}$ on the inoculated isolates. The ZI produced by the synthetic drugs and plant extracts were observed and the diameter was measured by measuring scale in millimetre $(\mathrm{mm})$.

\section{Statistical analysis:}

Various data collected were subjected to both descriptive and inferential statistics at $\mathrm{p}<0.05$ significant level. SPSS version 18.0 package was used for the analysis (Duncan, 1955).

\section{RESULTS}

Bacterial characteristics, identification of isolates and occurrence:

Result of the microbiological analyses of Clarias gariepinus samples revealed that eight bacteria were identified, namely; Echerichia coli, Bacillus megaterium, Enterobacter spp, Stapyllococcus aureus, Bacillus subtilis, Aeromonas hydrophila, Citrobacter spp. and Klebsiela spp. However, six isolates could not be properly identified. Occurrences' percentages and frequencies of identified bacteria are presented in Table 1. It was indicated that Escherichia coli $(50.00 \%)$ had the highest occurrence followed by Citrobacter spp. $(11.72 \%)$ and then Staphylococcus aureus (8.82\%), followed by Bacillus subtiles (8.82\%), Bacillus megaterium (5.88\%), Enterobacter sp. (5.88\%), Klebsiela sp. $(5.88 \%)$ and Aeromonas sp. The total number of isolates was 34 . 
Table 1. Percentage of bacterial occurrences isolated from Clarias gariepinus

\begin{tabular}{|l|l|}
\hline Bacteria isolates & \% No. of occurrence \\
\hline Aeromonas hydrophila & $2.94 \%(1)$ \\
\hline Bacillus megaterium & $5.88 \%(2)$ \\
\hline Bacillus subtilis & $8.82 \%(3)$ \\
\hline Citrobacter sp & $11.76 \%(4)$ \\
\hline Esherichia coli & $50.00 \%(17)$ \\
\hline Enterobacter sp & $5.88 \%(2)$ \\
\hline Klebsiela spp & $5.88 \%(2)$ \\
\hline Staphyllococcus aureus & $8.82 \%(3)$ \\
\hline Grand Total & $\mathbf{1 0 0 . 0 0 \% ( 3 4 )}$ \\
\hline
\end{tabular}

\section{Antibacterial activities of synthetic antibiotics:}

The results in Table $\mathbf{2}$ indicated the sensitivities of all the isolated bacteria subjected to synthetic antibiotics; CPX, PEF and OFX were the most effective with mean sensitivity values of $6.93 \mathrm{~mm}, 6.48 \mathrm{~mm}$ and $6.10 \mathrm{~mm}$, respectively.

Table 2. Antibacterial activity of selected antibiotics against bacterial isolated from the Clarias gariepinus

\begin{tabular}{|c|c|c|c|c|c|c|c|c|c|c|}
\hline Bacterial isolates & $\begin{array}{l}\text { SXT } \\
(\mathrm{mm})\end{array}$ & $\begin{array}{l}\mathrm{CH} \\
(\mathrm{mm})\end{array}$ & $\begin{array}{l}\text { SP } \\
(\mathrm{mm})\end{array}$ & $\begin{array}{l}\text { CPX } \\
(\mathrm{mm})\end{array}$ & $\begin{array}{l}\text { AM } \\
(\mathrm{mm})\end{array}$ & $\begin{array}{l}\text { AU } \\
(\mathrm{mm})\end{array}$ & $\begin{array}{l}\text { CN } \\
(\mathrm{mm})\end{array}$ & $\begin{array}{l}\text { PEF } \\
(\mathrm{mm})\end{array}$ & $\begin{array}{l}\text { OFX } \\
(\mathrm{mm})\end{array}$ & $S(\mathrm{~mm})$ \\
\hline Bacillus megaterium & 0.00 & 0.00 & 1.50 & 4.00 & 0.00 & 0.00 & 0.75 & 3.00 & 7.25 & 7.50 \\
\hline Bacillus subtilis & 4.67 & 5.00 & 4.00 & 9.00 & 1.33 & 0.17 & 4.00 & 8.50 & 8.00 & 5.33 \\
\hline Klebsiela sp. & 0.00 & 0.00 & 5.00 & 9.00 & 0.00 & 0.00 & 0.50 & 9.00 & 9.00 & 1.50 \\
\hline Aeromonas hydrophila & 0.00 & 0.00 & 0.00 & 10.00 & 0.00 & 0.00 & 6.00 & 9.00 & 0.00 & 0.00 \\
\hline Citrobacter $\mathrm{sp}$ & 0.00 & 1.38 & 2.25 & 7.75 & 0.00 & 0.00 & 2.13 & 7.75 & 6.75 & 3.38 \\
\hline E. coli & 1.41 & 1.29 & 2.00 & 5.47 & 0.47 & 0.18 & 2.29 & 4.91 & 4.65 & 2.09 \\
\hline Enterobacter & 10.00 & 8.00 & 5.00 & 10.00 & 0.00 & 0.00 & 6.00 & 10.00 & 10.00 & 10.00 \\
\hline Enterobacter sp & 0.00 & 0.00 & 0.00 & 9.00 & 0.00 & 0.00 & 1.00 & 8.00 & 7.00 & 4.00 \\
\hline Klebsiela sp & 0.00 & 0.00 & 3.50 & 9.00 & 0.00 & 0.00 & 0.00 & 9.00 & 7.00 & 0.00 \\
\hline Staphylococcus aureus & 2.67 & 2.67 & 2.67 & 6.00 & 2.67 & 2.67 & 4.67 & 8.67 & 7.67 & 4.00 \\
\hline Grand Total & 1.5 & 1.48 & 2.42 & 6.93 & 0.48 & 0.27 & 2.52 & 6.48 & 6.10 & 2.81 \\
\hline
\end{tabular}

Key: CH - chloramphenicol; SXT - Sparfloxacin; SP - Streptomycin; CPX-Ciprofloxacine; AM-Amoxacillin; AU - Augmentin; CN-Centamycin; PEF - Perfloxacin; OFX - Ofloxacin; S - Septrin.

Antibacterial activity of plants extracts and ciprofloxacin:

The result of the antibacterial activity of synthetic antibiotics was shown in Table 3, the result indicated that $M$. charantia was more effective than CFX against most of the isolated bacteria - B. megaterium (20 mm), Enterobacter sp. (2 $5 \mathrm{~mm})$, B. subtilis (23 mm), A. hydrophylla (23 $\mathrm{mm}$ ) and Citrobacter sp (19 mm), except for S. aureus and Kleb spp. but had same effect on $E$. coli (10 mm). The activities zone of ethanol extract $M$. charantia ranged between $10.00-25.00 \mathrm{~mm}$ while the activities zones of CPX ranged between 1.3-15.1 mm (Table 3).

Table 3. Antibacterial activity of ciprofloxacin (CPX) and different extracts of Mimosa pudica and Mormodica charantia against the isolated bacteria

\begin{tabular}{|c|c|c|c|c|c|c|c|}
\hline \multirow[t]{2}{*}{ Bacterial Isolates } & \multicolumn{2}{|c|}{ Aqueous Extracts } & \multicolumn{2}{|c|}{ Sterile Distilled Water Extracts } & \multicolumn{2}{|c|}{ Ethanol Extracts } & \multirow[t]{2}{*}{ CPX (synthetic) } \\
\hline & M. pudica & M. charantia & M. pudica & M. charantia & M. pudica & M. charantia & \\
\hline E. coli & - & $10 \mathrm{~mm}$ & - & - & - & - & $10 \mathrm{~mm}$ \\
\hline B. megaterium & - & $20 \mathrm{~mm}$ & - & - & - & - & $1.30 \mathrm{~mm}$ \\
\hline Enterobacter sp. & - & $25 \mathrm{~mm}$ & - & - & - & - & $13.35 \mathrm{~mm}$ \\
\hline Staphyllus aureus & - & $13 \mathrm{~mm}$ & - & - & - & - & $14.50 \mathrm{~mm}$ \\
\hline Bacillus subtilis & - & $23 \mathrm{~mm}$ & - & - & - & - & $10.30 \mathrm{~mm}$ \\
\hline $\begin{array}{l}\text { Aeromonas } \\
\text { hydrophylla }\end{array}$ & - & $23 \mathrm{~mm}$ & - & - & - & - & $9.80 \mathrm{~mm}$ \\
\hline Citrobacter sp & - & $19 \mathrm{~mm}$ & - & - & - & - & $10.90 \mathrm{~mm}$ \\
\hline Klebsiela spp & - & $10 \mathrm{~mm}$ & - & - & - & - & $15.10 \mathrm{~mm}$ \\
\hline
\end{tabular}

Phytochemicals composition of tested plants' extracts:

Table 4 presents the composition of some bioactive components of both $M$. charantia and $M$. pudica. Result revealed the highest concentration of Tannin $(7.25 \mathrm{mg} / 100 \mathrm{~mL})$ in the ethanolic extract of $M$. charantia and the least concentration of Anthocyanin in the aqueous extract of $M$. pudica $(0.10 \mathrm{mg} / 100 \mathrm{~mL})$.

Table 4. Phytochemicals composition of extracts of Mormodica charantia and Mimosa pudica

\begin{tabular}{|l|l|l|l|l|}
\hline \multirow{2}{*}{$\begin{array}{l}\text { Phytochemical } \\
\text { (mg/100mL) }\end{array}$} & M. charantia & M. pudica \\
\cline { 2 - 5 } & Ethanolic & 0.18 & Ethanolic & Aqueous \\
\hline Steriod & 0.25 & 0.76 & 0.19 & 0.11 \\
\hline Alkaloids & 0.98 & 0.65 & 0.75 & 0.66 \\
\hline Phenols & 0.98 & 6.15 & 0.49 & 0.42 \\
\hline Tannins & 7.25 & 1.45 & 5.22 & 5.14 \\
\hline Flavonoids & 1.65 & 1.20 & 1.27 & 1.21 \\
\hline Saponin & 1.32 & 0.15 & 1.22 & 1.16 \\
\hline Terpenoid & 0.20 & 0.12 & 0.15 & 0.13 \\
\hline Anthocyanin & 0.19 & 0.25 & 0.13 & 0.10 \\
\hline Anthraquinone & 0.45 & 0.29 & 0.19 \\
\hline
\end{tabular}


The minimum inhibitory concentration (MIC) is the lowest concentration of antimicrobial, which inhibits the growth of an organism. The MICs of $M$. charantia aqueous extract against $B$. megaterium was $1.56 \mathrm{mg}$, Enterobacter sp. $1.13 \mathrm{mg}$ and against $B$. subtilis was $3.13 \mathrm{mg}$. However, high and same value of $25 \mathrm{~mm}$ was recorded for A. hydrophylla, Citrobacter sp. and Klebsiela sp.

\section{DISCUSSION}

Results concerning the existence of various bacteria were similar to the findings of Tipezenji (2017) who observed the presence of Staphylococcus aureus, Bacillus spp., Psudomonas spp. and Citrobacter spp. from the different organs of $C$. gariepinus obtained in Lake Kariba in Zambia. Also, the recorded numbers of unidentified bacteria were similar to the current study. This could be attributed to the emergence of a new set of bacteria in C. gariepinus. The common isolates reported in this study was also corroborated by the findings of Mailafia and Anjorin (2017) who studied the antimicrobial susceptibility pattern of bacteria isolated from gastrointestinal tract of freshwater fishes in Abuja, Nigeria. On the other hand, the result of this study was not in concordance with the order of prevalence reported by Goswam et al. (2011). However, there is a need for further characterization methods especially with the use of microbiological kits and molecular characterization for better identification in the nearest future. Furthermore, among all bacterial families, the family Enterobacteriaceae; e.g. Escherichia coli, especially the coliforms, are relatively the leading organism in freshwater fish as observed in this study. This could be attributed to the fact that fishes are exposed to a faecal contaminated water source, contaminated feed and environment where they are cultured or inhibited (Olafsen, 2001).

The prevention of epidemic disease and control of pathogens multiplication by antibiotics and chemotherapeutics has caused the emergence of drug-resistant bacteria. According to Sahoo and Mukherjee (1997) and Zhang et al. (2005), presently, a good number of antibiotics such as oxytetracycline, ciprofloxacin, norfloxacin, chloramphenicol, gentamicin, cefazolin and aztreonam for tetracyclineresistant strains have been used successfully to control infectious diseases. Several studies have reported the efficacy of various synthetic antibiotics in controlling bacterial infections in fish. In this way, Ghaly et al. (2015) reported that ciprofloxacin (CPX) appeared as an effective antibiotic in the treatment of fish bacterial infection especially Aeromonas spp.

In this study, Tannin compound was observed to have the highest present, among other compounds, in both plants ( $M$. pudica and M. charantia). Tannin compounds have been reported to be present in many medicinal plants such as Acacia sieberiana, Albizia adianthifolia, Ficus sur and Ximenia caffra. Tannins bind with metal ions to form chelates and it has astringent properties which induce complexities with substrates' enzymes. Many microbial enzymes in purified forms or in raw culture filtrates are inhibited when contact tannin or tannic acid; it has a toxic effect on the membranes of microorganisms. Tannic acid was found to inhibit the growth of intestinal bacteria such as Clostridium perfringens, Escherichia coli Enterobacter cloacae and Bacteroides fragilis. Chung et al. (1998) reported that the strong iron-binding capacity of tannic acid inhibits the growth of bacteria in the intestine. These bacteria require iron for a variety of functions, formation of haem, reduction of the ribonucleotide precursor of DNA, and other essential purposes.

The low MICs of the $M$. charantia extract showed its effectiveness against $E$. coli which threatens food safety as it causes diarrhea in human. The inhibition concentration of the extract; for B. megaterium (1.56 mg), Enterobacter sp. (1.13 mg) and B. subtilis (3.13 mg) and high with the same values for $A$ hydrophylla, Citrobacter sp. and Klebsiela $s p$.

\section{CONCLUSION}

Ethanol extract of Momordica charantia has a promising antibacterial effect on isolates of $C$. gariepinus and could be used as a multiple antibiotics for the treatment of bacterial diseases in catfish. However, synthetic antibiotic, ciprofloxacin is the most effective antibiotics for multiple treatments of bacteria but bacterial resistance increases after repeated use of synthetic antibiotics. Invariably, the high prevalence of $E$. coli signifies the exposure of the fishes to faecal waste in their culture medium or/and the water they were collected. Because of this, extracts of $M$. charantia can be used in the treatment of infection in fish as antimicrobial agents against fungal and bacterial infections.

Conflict of Interest: The authors declare no conflict of interest

\section{REFERENCES}

Alimi, A.A. (2015). Challenge of Clarias gariepinus (Burchell, 1822) with Aeromonas sobria and its sensitivity to synthetic antibiotics and plant extracts. M. Sc. Dissertation. Federal University of Agriculture, Abeokuta, Ogun State, Nigeria. 136 pp.

Balakumar, S., Rajan, S., Thirunalasundari, T., \& Jeeva, S. (2011). Antifungal activity of Aegle marmelos (L.) Correa (Rutaceae) leaf extract on dermatophytes. Asian Pac J. Trop. Biomed., 1(4), 309-312.

Cefalu, W.T., Ye, J., \& Wang, Z.Q. (2008). Efficacy of dietary supplementation with botanicals on carbohydrate metabolism in humans.endocrine, Metabolic and Immune disorders-Drug Targets, 8,78-81.

Chung, K.T., Wong, T.Y., Wei, C.I., Huang, Y.W., \& Lin, Y. (1998). Tannins and human health: a review. Critical Reviews in Food Science and Nutrition, 38, 421-64.

Doss, A., Vijayasanthi, M., Parivuguna, V., \& Anand, S.P. (2011). Evaluation of antibacterial properties of ethanol and flavonoids from Mimosa pudica linn and Panicum maxi. jacq. Plant Science of Feed, 1(2), 39-44.

Duncan, D.B. (1955). Multiple range and multiple F tests. Biometrics, 11, 1-42.

Edeoga, H.O., Okwu, D.E., \& Mbaebie, B.O. (2005). Photochemical constituents of some Nigerian Medicinal plants. Afr. J. Biotechnol., 4(7), 685-688.

Ghaly, F. M.,; Dina, M. Baraka, S., Shahira, H. Mahmoud, H., Sohair, S., EL-Salam, A., Somayah, M., Abeer, A., \& EL-Makhzangy, A. (2015). Efficacy of Ciprofloxacin and Clove Extract on Bacterial Infection of Clarias gariepinus. Middle East Journal of Applied Scence, 5, 01-09.

Goswami, N., Goswami, A.P., Tripathi, C., Trivedi, H., \& Patel, T. (2011). Antibiotic sensitivity profile of bacterial pathogens in postoperative wound infections at a tertiary care hospital in Gujarat, India. Journal of Pharmacology and Pharmacotherapeutics, 2(3),158-500.

Harborne, J. B., \& Williams,C.A. (2000). Advances in flavonoid research. Photochemistry, 55, 481-504

Hastein, T., Hjeltnes, B., Lillehaug, A., Utne Skare, J., Berntssen, M., \& Lundebye, A.K., (2006). Food Safety hazards that occur during the production stage: challenges for fish farming and the fishing industry. Review of Science and Technology, 25(2),607-625.

Holt,J.G., Krieg, N.R., Sneath, P.H.A., Stanley, J.T., \& Williams, S.T. (1994). Bergey's Manual of Determinative Bacteriology(9th ed.),Williams \& Wilkins, Co.,Baltimore.

Jadhav, J.P., \& Govindwar, S.P. (2006). Biotransformation of malachite green by Saccharomyces cerevisiae MTCC 463. Yeast, 23, $315-323$.

Kiruba, S., Jeeva, S., \& Mishra, B.P. (2011). Phytochemical analysis of the flower extracts of Rhododendron arboreum Small species. Nilagiricum (Zenker) Tagg. Asian Pacific Journal of Tropical Biomedicine, 1, 278-280.

Mailafia, S., \& Anjorin, S.T. (2017). Occurrence and Antimicrobial Susceptibility Pattern of Bacteria Isolated from Gastrointestinal Tract of Fresh Water Fishes in Abuja, Nigeria. International Journal on Curriculum Microbiology of Applied Sciences, 6(4), $2735-2743$. 
Nair, R., Kalariya, T., \& Sumitra, C. (2005). Antibacterial activity of some selected Indian Medicinal Flora. Turk. Journal of Botany, $29,41-47$. Obi, S.K.C., and Krakowiaka, A. (1983). Theory and Practice of Food Microbiology (Unpublished manual).

Okigbo, R.N., \& Ogbonnaya, U.O. (2006). Antifungal effects of two tropical plant leaf extracts (Ocimum gratissimum and Aframomum melegueta) on postharvest yam (Dioscorea spp.) rot. African Journal of Biotechnology, 5,1- 9

Olafsen, J.A. (2001). Interactions between fish larvae and bacteria in marine aquaculture. Journal of Aquaculture, 233-247.

Rahman, M.M., \& Hossain,M.N. (2010). Antibiotic and herbal sensitivity of some Aeromonas sp. isolates collected from diseased carp fishes. Progressive Agriculture, 21(1and2), 117-129.

Rajan, S., Thirunalasundari, T., \& Jeeva, S. (2011). Anti-enteric bacterial activity and phytochemical analysis of the seed kernel extract of Mangifera indica Linnaeus against Shigella dysenteriae (Shiga, corrig.) Castellani and Chalmers. Asian Pacific Journal of Tropical Medicine, 4(4), 294-300.

Rates, S.M.K. (2001). Plants as source of drugs. Toxicon, 39, 603-613.

Sahoo, P.K., \& Mukherjee,S.C. (1997). In-vitro susceptibility of three bacterial pathogens of catfish to 23 antimicrobial agents; Indian J. Fish., 44, 393-397

Santos P.R.V.,Oliveira, A.C.X., \& Tomassini,T.C.B. (1995). Control microbiogicide products. Fitoterapicos Review on Farming Bioquim, 31, 3538.

Satish, K., Dasika, M.S.M., \& Maranas,C.D. (2007). Antifungal activity of some plant extracts against important seed borne pathogens of Aspergillus sp. Journal of Agricultural Technology, 3 (1), 109-119.

Singh, J., Cumming, E., Manmohan, G., Kalasz, H., \& Adeghate, E. (2011). The Open Medicinal Chemistry Journal, 59, $70-77$.

Sukanya, S. L., Sudisha, J., Hariprasad, P., Niranjana, S.R., Prakash, H.S., \& Fathima, S.K. (2009). Antimicrobial activity of leaf extracts of Indian medicinal plants against clinical and phytopathogenic bacteria. African Journal of Biotechnology, 8(23), 6677-6682.

Tipezenji, S. (2017). Identification and Antibiogram Profiles of Bacteria Associated with Diseased Oreochromis Niloticus In Lake Kariba, Zambia. A Dissertation Submitted in Partial Fulfilment of the Requirements for the Degree of Master of Science in Health of Aquatic Animal Resources of Sokoine University of Agriculture. Morogoro, Tanzania.

Zhang, X.J., Fang, H., Chen, C.Z., GE, M.X., \& Wang, X.Y. (2005). Sensitivity of pathogenic Edwardsiella tarda isolated from flounder (Paralichthys olivaceus) to some antimicrobial agents. Fish Science, 24, 15-18.

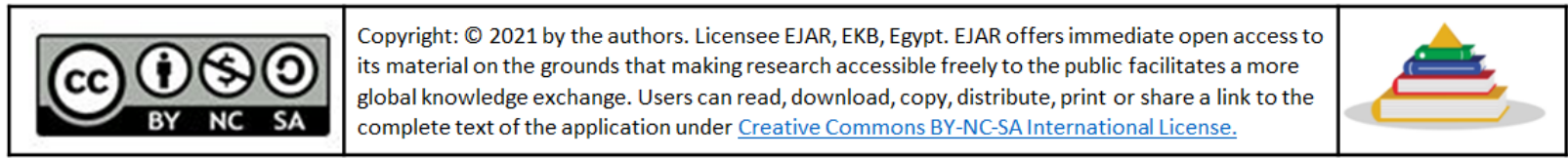




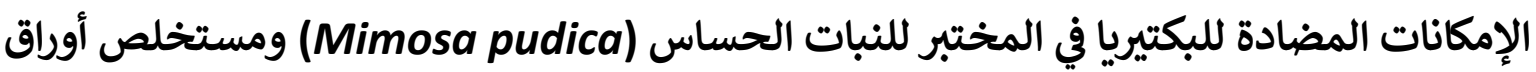

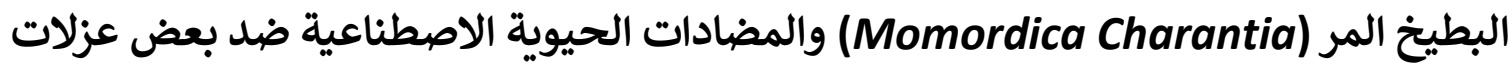
Clarias gariepinus بكتيريات

Adekunle Adedoyin Idowu ${ }^{1}$, Azeez Ayodele Alimi ${ }^{1 *}{ }_{\mathbb{C}}$, Adeleke Taofik Towolawi $^{2}$, Abiodun Oluwole Akinde ${ }^{1}$, Kolapo Fasina ${ }^{3}$ and Joy Aigbemekhe ${ }^{1}$

1قسم تربية الأحياء المائية وإدارة مصايد الأسماك ، الجامعة الفيدرالية للزراعة ، أبيوكوتا (FUNAAB) ، نيجيريا.

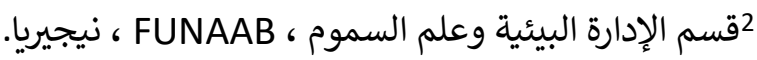

3قسم الأحياء الدقيقة ، FUNAAB ، منيجية السيريا.

alimiazees911@gmail.com:بريد المؤلف المراسل *

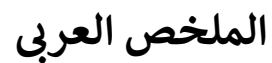

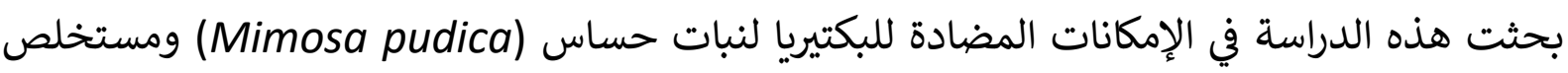

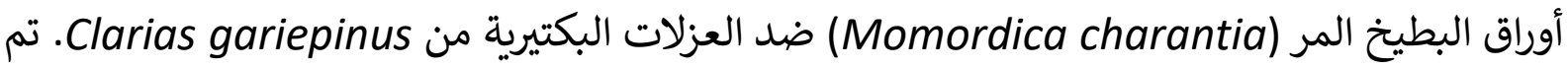

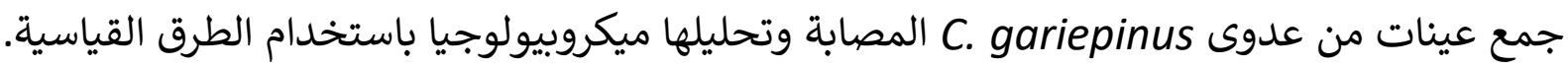

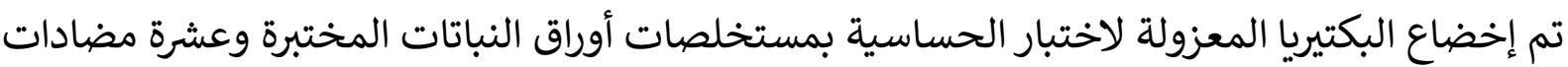

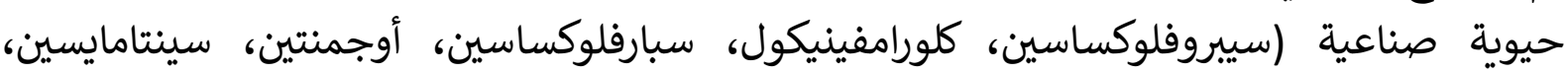

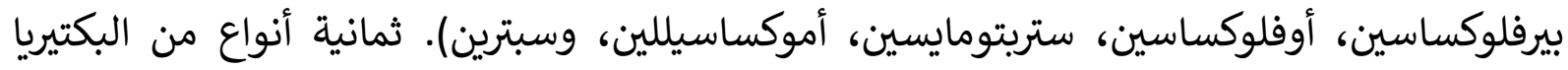

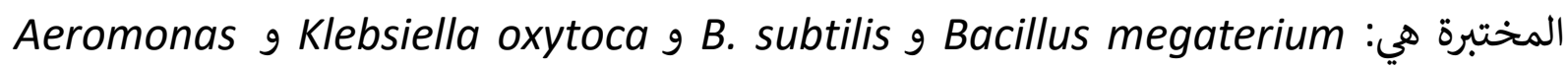
9 .Enterobacter spp g Escherichia coli g Citrobacter spp g hydrophila ألظهرت النتائج أن المستخلص الإيثانولي لنبات Staphyllococcus aureus

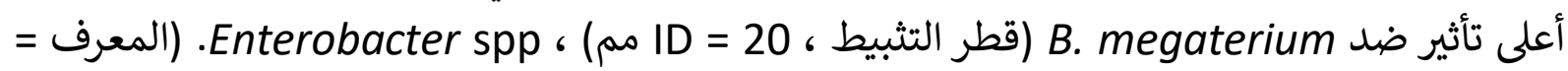

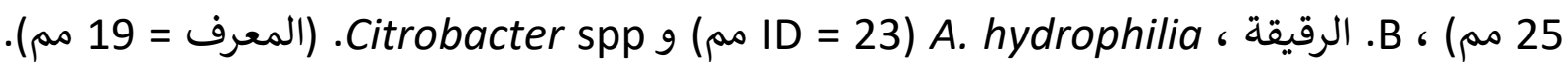

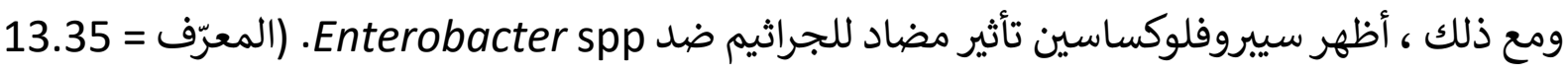

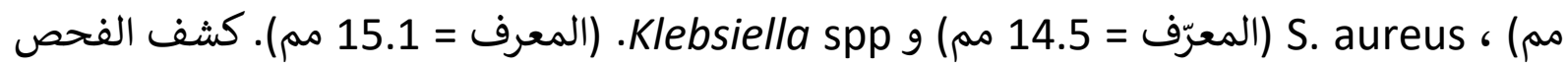

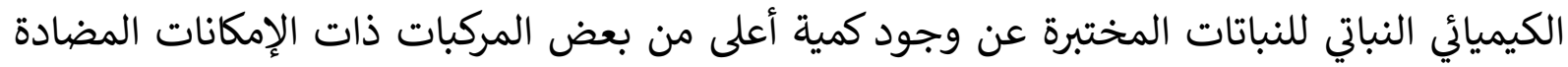

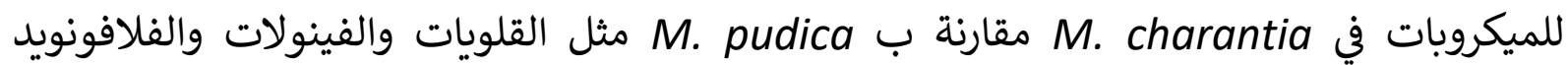

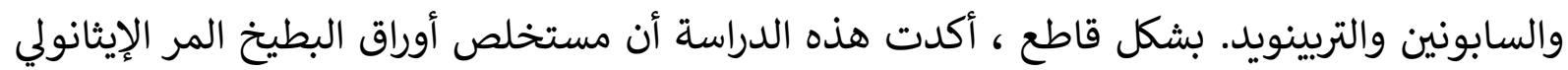

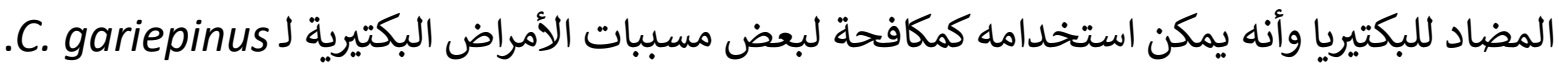

الكلمات المفتاحية: نباتات طبية، مستخلصات أوراق الشجر، مضادات الميكروبات، عزلات بكتيرية 